\title{
Peningkatan Efektivitas Kinerja Guru Pendidikan Agama Islam melalui Manajemen Evaluasi di SMA Negeri 7 Muaro Jambi
}

\author{
Fadlilah $^{1}$, Dian Nisa Istofa ${ }^{2}$ \& Fitra Rantika Sari ${ }^{3}$ \\ Universitas Islam Negeri Sulthan Thaha Saifuddin, Jambi \\ *corresponding author: fadlilah@gmail.com
}

\begin{abstract}
:
This research aims to find out the evaluation of the performance of Islamic religious education teachers at Sma Negeri 7 Muaro Jambi. This research uses descriptive qualitative research methods. Data is collected by observation, interview, and documentation. The results showed that Sma Negeri 7 Muaro Jambi implemented the implementation of teacher performance evaluation program management held in each semester. The evaluation and monitoring activities are carried out directly by the principal and the Ministry of Religious Affairs. The evaluation program for the performance management of Islamic religious education teachers went quite well. Teachers always report their performance results shown through the learning outcomes of students who continue to experience improvement.
\end{abstract}

KEYWORDS: Performance ampheivity; PAI teacher; evaluation management.

\begin{abstract}
ABSTRAK:
Penelitian ini bertujuan untuk mengetahui evaluasi kinerja guru pendidikan agama Islam di SMA Negeri 7 Muaro Jambi. Penelitian ini menggunakan metode penelitian kualitatif deskriptif. Data dikumpulkan dengan cara observasi, wawancara, dan dokumentasi. Hasil penelitian menunjukkan SMA Negeri 7 Muaro Jambi menerapkan pemberlakuan manajemen program evaluasi kinerja guru yang diadakan pada tiap semester. Kegiatan evaluasi dan monitoring tersebut dilakukan langsung oleh kepala sekolah dan Kementrian Agama. Program evaluasi manajemen kinerja guru pendidikan agama Islam berjalan cukup baik. Para guru selalu melaporkan hasil kinerjanya yang ditunjukkan melalui hasil belajar siswa yang terus mengalami peningkatan.
\end{abstract}

KATA KUNCI: Efetivitas kinerja; guru PAI; manajemen evaluasi.

Copyright @ Published by Program Studi Manajemen Pendidikan Islam Fakultas Tarbiyah dan Keguruan

Universitas Islam Negeri Sulthan Thaha Saifuddin jambi

Mendalo Darat, Muaro Jambi, 36361, Indonesia 


\section{PENDAHULUAN}

Manajemen evaluasi kinerja guru merupakan upaya untuk mencapai suatu tujuan dalam membentuk penilaian dalam kinerja seorang guru. Kegiatan peningkatan kinerja guru dapat dilaksanakan melalui dua pendekatan yaitu kegiatan internal sekolah dan kegiatan eksternal sekolah. Kegiatan internal sekolah mencakup; a) supervisi yang dilakukan oleh kepala sekolah dan para pengawas dari kantor Dinas Pendidikan setempat untuk meningkatkan kualitas guru, b) program Musyawarah Guru Mata Pelajaran (MGMP) yang direncanakan dan dilaksanakan secara teratur, terus-menerus dan berkelanjutan, c) kepala sekolah melakukan kegiatan pengawasan yang berencana, efektif dan berkesinambungan, d) kepala sekolah dapat memotivasi dan memberikan kesempatan kepada guru-guru untuk mengikuti kegiatan seminar atau lokakarya dan penataran dalam bidang yang terkait dengan keahlian guru yang bersangkutan dengan cara mendatangkan para ahli yang relevan. Sedangkan kegiatan eksternal sekolah dapat dilakukan di luar sekolah dengan tujuan untuk meningkatkan kompetensi dan kinerja guru dalam mengajar. Hal ini dapat dilakukan dengan mengikuti kegiatan penataran dan pelatihan yang direncanakan secara baik, dilaksanakan di tingkat kabupaten atau kota, propinsi dan tingkat nasional untuk meningkatkan pengetahuan dan keterampilan mengajar guru (Sholahudin, 2013).

Kinerja seseorang dipengaruhi oleh kondisi fisiknya. Seseorang yang memiliki kondisi yang baik memiliki daya tahan tubuh yang tinggi yang pada gilirannya tercermin pada kegairahan bekerja dengan tingkat produktivitas tinggi, dan begitu juga sebaliknya. Di samping itu kinerja individu berhubungan juga dengan kemampuan yang harus dimiliki oleh individu agar ia berperan dalam organisasi (Siagian, 2002). Kinerja tidak dapat timbul dengan sendirinya, di samping adanya usaha dan kemampuan, kinerja juga dipengaruhi oleh faktor lain. Dilihat dari sudut motivasi, khususnya ganjaran yang akan diperoleh sehubungan dengan adanya kinerja, seorang akan melihat bahwa kinerja merupakan jalan yang memuaskan kebutuhan. Kebutuhan berhubungan dengan kekurangan yang dialami oleh seseorang pada waktu tertentu. Kebutuhan dipandang sebagai pembangkit, penguat atau penggerak perilaku, artinya apabila terdapat kekurangan kebutuhan maka orang lebih peka terhadap usaha motivasi dari manajer. 
Pengukuran kinerja dapat dilakukan dalam berbagai kegiatan, antara lain kegiatan tahap proses dan tahap hasil. Dari kegiatan tersebut dapat dibedakan menjadi tiga kriteria tujuan pengukuran, yaitu tujuan administratif, supervisi atau konseling, dan penelitian. Data yang diperoleh akan dapat dimanfaatkan memvalidasi prosedur seleksi, evalusi program, evaluasi motivasi, dan kepuasan kinerja. Evaluasi adalah proses kegiatan berangkai mulai dari pengumpulan informasi, penetapan kriteria, membentuk penilaian dan menarik kesimpulan serta mengambil keputusan pelaksanaan informasi. Manajemen adalah usaha atau kegiatan dua orang atau lebih untuk mencapai suatu tujuan organisasi secara efektif dan efisien, dan kegiatan penggunaan sumber-sumber daya organisasi untuk mencapai tujuan organisasi.

Guru memiliki peran yang strategis dalam bidang pendidikan. Guru adalah ujung tombak pendidikan sebab guru secara langsung berupaya mempengaruhi dan mengembangkan kemampuan siswa menjadi manusia yang cerdas, terampil dan bermoral tinggi. Sebagaimana ujung tombak guru dituntut memiliki kemampuan dasar yang diperlukan sebagai pendidik dan pengajar (Nana Sudjana, 2004). Guru merupakan kunci utama dalam upaya peningkatan kualitas pendidikan. Guru professional adalah guru yang memiliki kompetensi yang dipersyaratkan untuk melakukan tugas pendidikan dan pengajaran. Kompetensi disini meliputi pengetahuan, sikap, dan ketrampilan professional, baik yang bersifat pribadi, sosial maupun akademis.

Kinerja guru adalah hasil yang dicapai oleh guru dalam pelaksanaan tugas mengajar yang bermutu. Dalam penelitian ini, kinerja guru dimaksudkan sebagai unjuk kerja dalam pelaksanaan tugas mengajar dengan empat indikator, yaitu: (1) kinerja dalam perencanaan pembelajaran, (2) kinerja dalam pelaksanaan pembelajaran, (3) kinerja dalam penilaian pembelajaran, dan (4) kinerja dalam pengembangan profesi. Aspek-aspek dalam keempat indicator inilah yang dijadikan standar minimum kinerja guru dalam penelitian ini.

Kinerja guru professional adalah orang yang memiliki kemampuan dan keahlian khusus dalam bidang keguruan sehingga ia mampu melakukan tugas dan fungsinya sebagai guru dengan kemampuan maksimal. Guru yang professional adalah orang yang terdidik dan terlatih dengan baik, serta memiliki pengalaman yang kaya dibidangnya. Keberhasilan seorang guru harus memenuhi kriteria yang ditetapkan serta memiliki kinerja yang bagus, apabila guru telah memenuhi kritria tersebut, berarti seorang guru dapat dikatakan 
berhasil dan memiliki kualitas yang baik. Sebaliknya apabila seorang guru belum memenuhi kriteria yang baik, maka guru belum dapat dikatakan berhasil. Penelitian ini bertujuan adalah untuk mengetahui manajemen evaluasi dalam meningkatkan kinerja guru PAI di SMA N 7 Muaro Jambi. Penilaian kinerja guru dimaksud untuk meningkatkan kualitas pendidikan siswa.

\section{METODE}

Penelitian ini menggunakan metode deskriptif kualitatif. Data dikumpulkan melalui observasi, wawancara, dan dokumentasi. Data hasil wawancara dan telaah dokumentasi dianalisis secara kualitatif dengan teknik analisis deskriptif kualitatif dari Miles dan Huberman. Teknik analisis menggunakan teknik analisis yang dikemukakan oleh Miles dan Huberman yakni reduksi data, penyajian data, dan penarik kesimpulan (Sugiyono, 2014). Teknik keabsahan data menggunakan teknik triangulasi yang bertujuan untuk mengecek kebenaran dan keabsahan data-data yang diperoleh di lapangan dalam meningkatkan animo masyarakat di MA Al-Azhar Muaro Bungo. Analisis data dilakukan secara kuantitatif dan kualitatif sesuai dengan jenis data yang dikumpulkan.

\section{HASIL PENELITIAN DAN PEMBAHASAN}

Evaluasi yaitu kegiatan yang terencana untuk mengetahui keadaan sesuatu obyek dengan menggunakan instrumen dan hasilnya dibandingkan dengan tolak ukur untuk memperoleh kesimpulan. Menurut Edwind dan Gerald W. Brown dalam bukunya Sulistyorini bahwa evaluasi adalah suatu tindakan atau suatu proses untuk menentukan nilai daripada sesuatu. Manajemen adalah keterampilan khusus untuk melakukan suatu kegiatan, baik bersama orang lain atau melalui orang lain dalam mencapai tujuan organisasi. Jadi yang peneliti maksud manajemen program evaluasi kinerja diskripsi ini adalah proses keterampilan yang dilakukan bersama untuk menilai suatu kinerja guru pendidikan agama islam yang sudah direncanakan sesuai dengan tanggung jawabnya.

Indikator bidang akademik dari aspek aplikasi pembelajaran terdiri dari tiga indikator yaitu peningkatan kemampuan dalam penguasaan Teknik atau metode mengajar, menerapkan pengajaran yang variatif, dan menggunakan 
metode yang tepat dalam pengajaran. Dalam aspek perencanaan pembelajaran terdiri dari lima indicator yaitu memiliki kurikulum yang berlaku, memiliki kalender, pendidikan, memiliki program semester, memiliki program tahunan, dan memiliki rencana pembelajaran. Dalam aspek pelaksanaan pembelajaran terdiri dari enam indicator yaitu memulai pembelajaran tepat waktu, memanfaatkan waktu pembelajaran dengan optimal, memberikan kesempatan kepada siswa untuk bertanya dan berpendapat, menggunakan suara yang jelas dan tegas dalam mengajar, melaksanakan pengelolaan kelas dengan baik, dan melaksanakan pembelajaran dengan rencana pelajaran yang sudah disusun. Unsur sumber belajar yang memiliki aspek ketersediaan bahan ajar terdiri dari tiga indicator yaitu memiliki buku pegangan utama yang sama seperti yang dimiliki siswa, memiliki buku penunjang yang mampu memperkaya materi pembelajaran dan memiliki daftar buku yang dapat digunakan siswa untuk memperkaya pengetahuan. Aspek pemanfaatan sumber belajar terdiri dari empat indicator yaitu guru mampu memanfaatkan media yang ada untuk pembelajaran, guru mampu memanfaatkan alat peraga yang ada, guru memiliki kemampuan untuk membuat alat peraga, memanfaatkan semua sumber belajarmyang ada (Instrument Penilaian Kinerja). Aspek kerja sama terdiri dari empat indikator yaitu dapat menyesuaikan pendapatnya dengan orang lain, mengetahui secara mendalam bidang tugas orang lain yang ada hubungannya dengan bidangnya sendiri, menghargai pendapat orang lain dan mampu bekerja bersama-sama dengan orang lain menurut waktu dan bidang yang sama. Sedangkan aspek inisiatif terdiri dari tiga indikator yaitu selalu berusaha memberikan saran dan pandangannya baik dan berguna kepada atasan baik diminta atau tidak diminta, tanpa petunjuk atau perintah atasan dalam melaksanakan tugas, dan berusaha mencari tatacara kerja baru dalam mencapai daya sebesar-besarnya.

Sekolah Menengah Atas 7 Nergeri Muaro Jambi sebagai suatu lembaga yang menerapkan pemberlakuan manajemen program evaluasi kinerja guru. Program ini diadakan pada setiap semester, kepala sekolah dan kementrian agama melakukan monitoring evaluasi, dengan tujuan para guru dapat meningkatkan pembelajaran. Dalam manajemen evaluasi kinerja guru pendidikan ini terdapat perencanaan, pengorganisasian, pelaksanaan serta pengawasan, yang di mana semua itu termasuk dalam prinsip manajemen. 
Peningkatan kinerja yang dinilai sudah dicapai diantaranya; (1) pada aspek perencanaan, guru telah mampu menyusun program tahunan, program semester, silabus, dan RPP, serta hasilnya sudah cukup lebih baik serta telah disusun lebih awal dari sebelumnya. Selain itu, RPP yang sebelumnya disusun untuk satu semester sekaligus, sekarang sudah dibuat pada setiap tatap muka (disesuaikan dengan kebutuhan), serta (2) pada aspek pelaksanaan pembelajaran, guru sudah menggunakan berbagai media/alat peraga. Meski demikian, tidak satupun dari responden kepala madrasah yang menyatakan kinerja guru sudah mencapai kinerja yang optimal atau mencapai standar kinerja yang berlaku, bahkan ada yang menilainya hanya mendekati standar kinerja.

Guru di SMAN 7 Muaro Jambi memiliki tanggung jawabnya tersendiri dalam mengajar, tanggung jawab yang harus di penuhi dalam setiap pengajaran. Terkhusus pada guru PAI yang berperan penting dalam pengembangan karakter siswa/siswi dalam karakter keagamaan. Manajemen program evaluasi kinerja guru di Sekolah Menengah Atas 7 Negeri Muaro Jambi dilakukan melalui kegiatan perencanaan dan pengorganisasian progam evaluasi kinerja guru sesuai dengan SK (Surat Keputusan). Hal tersebut tergantung pada kegiatan Rencana Kerja Sekolah (RKS), kemudian ditindaklanjuti melalui pos atau tugasnya masing-masing. Pelaksanaan dan pengawasan program evaluasi kinerja guru sudah terjadwal dalam RKS, tetapi RKS masih bersifat umum, kemudian dari RKS dibuatkan SK (Surat Keputusan) dan dijelaskan untuk dipahami bersama.

Hasil dalam evaluasi kinerja guru PAI di SMA Negeri 7 Muaro Jambi didasarkan pada penilaian hasil belajar yang merupakan kegiatan atau cara yang ditujukan untuk mengetahui tercapai atau tidaknya tujuan pembelajaran dan juga proses pembelajaran yang telah dilakukan. Pada tahap ini seorang guru dituntut memiliki kemampuan dalam menentukan pendekatan dan caracara evaluasi, penyusunan alat-alat evaluasi, pengolahan dan penggunaan hasil evaluasi. Manajemen evaluasi kinerja guru PAI di SMA Negeri 7 Muaro Jambi yaitu, guru PAI tersebut semakin memahami dan mendalami tentang PAI. Dalam pengorganisasian guru PAI tersebut dapat menjalankan tanggung jawab yang telah ditetapkan sebelumnya. Dalam pelaksanaan guru PAI tesebut telah bergerak sesuai dengan arahan yang telah diberikan sebelumnya oleh kepala sekolah, sehingga guru dapat memberikan hasil yang terbaik bagi kinerjanya. 
Pengawasan guru PAI sudah tercapai, dan yang telah direncanakan sejak awal sudah mencapai target yang telah ditentukan.

Pengawasan pada program manajemen evaluasi kinerja guru PAI di SMAN 7 Muaro Jambi juga mengalami kendala yang menghambat terlaksananya evaluasi kinerja guru. Kendala tersebut disebabkan adanya perbedaan parameter terhadap format penilaian kinerja yang digunakan antara tim evaluator dengan yang dievaluasi. Akan tetapi hal tersebut dapat diselesaikan melalui musyawarah untuk menyamakan persepsi, sehingga menghasilkan keputusan yang terbaik. Berdasarkan pengamatan peneliti, kendala tersebut terjadi karena tidak dilibatkannya guru dalam penyusunan instrumen atau format penilaian yang digunakan. Hal tersebut bertentangan dengan teori pengorganisasian yang mengharuskan adanya koordinasi yang baik antar anggota dalam sebuah organisasi. Artinya apabila dalam lembaga tersebut merencanakan suatu program, maka tujuan, prosedur, dan format yang akan digunakan harus disosialisasikan.

Evaluasi kinerja dalam hal ini disebut juga dengan penilaian kinerja. Penilaian dilakukan secara sistematis terhadap kinerja karyawan dan potensi untuk berkembang. Penilaian kinerja mencakup prestasi kerja, cara bekerja, dan pribadi. Sedangkan penilaian terhadap potensi untuk berkembang mencakup kreativitas dan hasil belajar atau kemampuan mengembangkan profesinya. Penilaian atau evaluasi kinerja guru sangat bermanfaat untuk mengevaluasi hasil kerja yang telah diperoleh. Dengan adanya penilaian kinerja guru, diharapkan dapat memberikan sumbangan yang berharga bagi sekolah bila dilakukan dengan sikap yang positif dan semangat Kerjasama antara petugas penilai dengan guru yang dinilai.

\section{SIMPULAN}

Sekolah Menengah Atas 7 Negeri Muaro Jambi sebagai suatu lembaga yang menerapkan pemberlakuan manajemen program evaluasi kinerja guru. Program ini diadakan pada setiap semester, kepala sekolah dan kementerian agama melakukan monitoring evaluasi, dengan tujuan para guru dapat meningkatkan pembelajaran. Hasil dari program evaluasi manajemen kinerja guru PAI terbilang baik, karna guru PAI tersebut selalu melaporkan peningkatan dalam nilai-nilai siswa dan siswi di SMA Negeri 7 Muaro Jambi tersebut. 
Program evaluasi kinerja guru berpegang pada prinsip manajemen yang dicetuskan oleh Terry, yang meliputi empat komponen, yaitu perencanaan, pengorganisasian, pelaksanaan dan pengawasan program evaluasi kinerja guru. Dalam perencanaan, disusun tujuan, format dan prosedur pelaksanaan program evaluasi kinerja guru. Tujuan tersebut adalah untuk mengevaluasi profesi teraplikasi, meningkatkan kinerja secara menyeluruh dan pemetaan guru secara menyeluruh. Format penilaian kinerja dibuat dan disusun oleh kepala sekolah beserta tim evaluator atas perintah dari ketua yayasan. Pengawasan program evaluasi kinerja guru dilakukan dalam waktu satu tahun satu kali. Dengan dilaksanakannya pengawasan akan membantu tim evaluator untuk bisa mengetahui apa saja yang menjadi kendala dalam melaksanakan proses evaluasi kinerja serta mencari solusinya, dan dengan pengawasan juga kita bisa mengetahui kekurangan dan kelebihan format, metode dan prosedur evaluasi kinerja, sehingga dapat menentukan langkah yang lebih baik untuk masa yang akan datang.

\section{REFERENSI}

Barnawi dan Mohammad Arifin. 2014. Kinerja Guru Profesional Intrumen Pembinaan, Peningatan \& Penilaian. Yogjakarta: Ar-Ruz Media.

InstrumenPenilaian Kinerja Departemen Pendidikan Nasional. Jakarta; Dirjen Dikdasmen: 2005. Lampiran 20.

Nasir, Usman. 2007. Manajemen Peningkatan Kinerja Guru. Bandung: Mutiara Ilmu.

Rianto Rahadi, Dedi. 2010. Manajemen Kinerja Sumber Daya Manusia. Malang: Tunggal Mandiri Publishing.

Sholahudin, Muhammad. 2013. "Evaluasi Kinerja Guru (Manajemen Evaluasi Peningkatan Profesionalitas Guru).” Tafaqquh, 1(1); 123-144.

Siagian, Sondang P. 2002. Manajemen Sumber Daya Manusia. Jakarta; PT. Bumi Aksara.

Sudjana, Nana. 2004. Pedoman Praktis Mengajar. Bandung: Dermaga.

Sugiyono. 2010. Metode Penelitian Pendidikan Pendekatan Kuantitatif, Kualitatif, dan RED . Bandung: Alfabeta.

Wibowo. 2014. Manajemen Kinerja. Jakarta: PT. Rajagrafido Persada. 